\title{
Growth Control of Cultured Microglia
}

\author{
S. Ganter, H. Northoff, D. Männel, P.J. Gebicke-Härter \\ Institute of Pharmacology, University of Freiburg (S.G.), Department of Psychiatry, University of Freiburg \\ Medical School (P.J.G.-H.) 7800 Freiburg i. Br., DRK-Blutspendezentrate, 7900 Ulm/Donau (H.N.), and Dt. \\ Krebsforschungszentrum, Department of Immunochemistry, 6900 Heidelberg (D.M.), Germany
}

Microglia, the resident macrophages of the brain, typically react to injuries or chronic diseases with proliferation and expression of differentiated features, such as production of cytokines associated with inflammatory events. Regulation and control of microglial cytokine expression, therefore, is a major focus of scientific interest. It has been shown that GMCSF and II-3 are potent mitogens for microglia. Moreover, Il-3 and other cytokines are products of microglia. It is shown here that interleukin-1 (II-1) as well as tumor necrosis factor (TNF ${ }_{\alpha}$ ) increased microglial proliferation in mixed astrocyte-microglial cultures but had no mitogenic effects on isolated microglia.

Lipopolysaccharide (LPS), the bacterial endotoxin, irreversibly inhibited microglial cell division in both mixed astrocyte-microglial cultures and in isolated microglial cultures. By contrast, the corticosteroids hydrocortisone and aldosterone and the synthetic glucocorticoid dexamethasone reversibly inhibited microglial proliferation. They also antagonized the stimulatory effects of Il-3 and granulocyte macrophage colony-stimulating factor (GMCSF). Estradiol and progesterone had no significant effects on mixed cultures but inhibited microglial proliferation in isolated cultures. Conditioned media from mixed cultures, isolated cultures, from the WEHI-2B cell line, or from fresh (serum-supplemented) media stimuIated microglial proliferation to various extents.

In summary, cytokine-mediated microglial proliferation can be down-regulated by a variety of steroid hormones. Along with their unimpaired access to brain cells in general, corticosteroids likely maintain an inhibitory tonus on microglial proliferation. It is hypothesized that this inhibition is overcome locally and temporally in brain injury and repair. (C) 1992 Wiley-Liss, Inc.

Key words: microglia, astroglia, lipopolysaccharide, cytokines, corticosteroids

\section{INTRODUCTION}

Microglia were first described in 1932 (del RioHortega, 1932) as a separate cell population of the brain.
Only recently, however, have their morphological (Mori and Leblond, 1969; Ling et al., 1973; Oehmichen, 1978; Rieske et al., 1989) and cytochemical (Ling, 1981; Perry et al., 1985; Giulian and Baker, 1986; Hayes et al., 1988; Schnitzer, 1989) properties been studied in greater detail. Microglia likely are cells of hematogenous origin. After migration into brain tissue during perinatal development, proliferating "ameboid cells" transform into quiescent, resting microglia within the following weeks (for review, see Cammermeyer, 1970; Giulian, 1987; Jordan and Thomas, 1988; Streit et al., 1988). Due to the brain-specific environment, they may express additional or lose typical features of peripheral mononuclear cells. They also retain a number of macrophage-like properties such as phagocytosis, expression of MHC-class I and II antigens, production of superoxide anions and cell killing (Rio-Hortega, 1932; Giulian, 1987). The activation of resting microglia is an important response to brain damage (Kreutzberg and Barron, 1976; Oehmichen, 1983; Giulian, 1987). Since induction of proliferation is one of the first steps of their activation, factors involved in up- and down-regulation of their proliferation have become a major focus of interest. Il-3 and GMCSF have been shown to be growth factors for microglia (Giulian and Ingeman, 1988), which is confirmed by our studies. Additional cytokines involved in inflammatory processes are II-1, Il-6, and TNF. Our investigations were aimed at elucidating the effects of these polypeptides as well as the effects of LPS and steroid hormones on microglial proliferation.

Received January 18, 1991; revised May 1, 1992; accepted May 4, 1992.

Address correspondence to P. J. Gebicke-Härter, Dept. of Psychiatry, University of Freiburg, Medical School, Haupt-str. 5, 7800 Freiburg i. Br., Germany.

Abbreviations: $\mathrm{ACM}$, astrocyte conditioned media; $\mathrm{CM}$, conditioned media; DMEM, Dulbecco's modified Eagle's medium; DMSO, dimethylsulfoxide; FCS, fetal calf serum; GMCSF, granulocyte macrophage colony-stimulating factor; GSA-I $\mathrm{B}_{4}$, lectin derived from Griffonia simplicifolia; Il, interleukin; LPS, lipopolysaccharide; MiCM, microglia conditioned media; NDPase, nucleoside diphosphatase; PBS, phosphate buffered saline; TNF, tumor necrosis factor; TPP, thiamine pyrophosphate; TPPase, thiamine pyrophosphatase; WEHI, WEHI-2B cell line. 


\section{MATERIALS}

Recombinant human Il-1 $\beta$ was purchased from BIOGEN (Cambridge, MA). Recombinant human $\mathrm{TNF}_{\alpha}$ was a generous gift from, BASF/Knoll (Ludwigshafen, FRG). Recombinant murine Il-3 and GMCSF were from GENZYME (Boston, MA). Corticosteroids, inosine diphosphate, TPP, peroxidase conjugated GSA-I- $\mathrm{B}_{4}$ lectin derived from Griffonia simplicifolia, and polyD-lysine were purchased from Sigma (Deisenhofen, FRG). RU 38486 (mifepristone) was generously supplied by Roussel Uclaf, (Romainville, France), and polyclonal rabbit antisera against murine Il-3 and murine GMCSF were obtained from Dr. de LaMarter (GLAXO, Geneva, Switzerland). IgG fractions of antisera, purified on Protein A-Sepharose (Pharmacia, Freiburg, FRG), were used in respective experiments. $\left[{ }^{3} \mathrm{H}\right]$-thymidine was from Amersham \& Buchler (Braunschweig, FRG). Lead citrate was purchased from Polyscience (Warrington, PA) and cacodylate buffer was from Roth (Karlsruhe, FRG). LPS-free FCS was obtained from PAN Systems (Aidenbach, FRG).

\section{METHODS}

\section{Cell Cultures}

Astroglial cells were prepared from cerebral hemispheres of newborn Wistar rats as described previously (Keller et al., 1985). After removal of the meninges, forebrains were minced and gently dissociated by trituration in Dulbecco's modified Eagle's medium (DMEM). Cells were collected by centrifugation at $200 g$ for $5 \mathrm{~min}$, resuspended in DMEM supplemented with $5 \%$ FCS (LPS-free), plated in $100 \mathrm{~mm}$ Costar culture dishes $\left(8 \times 10^{6} \mathrm{cells} / \mathrm{dish}\right)$, and maintained at $37^{\circ} \mathrm{C}$ in a humified atmosphere of $95 \%$ air, $5 \% \mathrm{CO}_{2}$.

\section{Microglial Proliferation in Mixed Cultures}

Cells were plated into 24-well culture-plates $(0.5$ $\times 10^{6}$ cells/well) and incubated at $37^{\circ} \mathrm{C}$ in a humified atmosphere of $95 \%$ air, $5 \% \mathrm{CO}_{2}$ in the presence or absence of LPS and with various concentrations of growth factors and growth inhibitors as indicated for 3 to 8 weeks. Floating microglia were harvested after 3,6 , or 8 weeks of culture and transferred into new 24-well culture-dishes. Two hours later attached microglia were counted. Accordingly, the influence of corticosteroids and $\mathrm{RU} 38486$ (a progesterone receptor antagonist) on microglial proliferation was analysed in 6-well plates $\left(10^{6}\right.$ cells/well). Mixed astrocyte/microglia cultures were maintained as described above in the presence of dexamethasone $\left(10^{-7} \mathrm{M}\right)$, hydrocortisone $\left(10^{-7} \mathrm{M}\right)$, estradiol $\left(10^{-6} \mathrm{M}\right)$, or progesterone $\left(10^{-6} \mathrm{M}\right)$ and in the presence or absence of RU $38486\left(10^{-4} \mathrm{~g} / \mathrm{L}\right)$ for the first 3 days of culture or for the whole culture time. Floating microglia were harvested after 4 weeks of culture and counted as described above.

\section{${ }^{3} \mathrm{H}$-Thymidine Incorporation Into Isolated Microglia}

Floating microglia from 3-week-old mixed astrocyte/microglia cultures were removed and reseeded into 96-well flat-bottomed microtiter plates (pure microglial cultures). They were maintained for $24 \mathrm{hr}$ in the presence of fresh (control) or conditioned media (CM) with or without growth factors or growth inhibiting substances as indicated in figures. Conditioned media were diluted at least twofold with fresh media. Then $\left[{ }^{3} \mathrm{H}\right]$-thymidine $(0.5 \mu \mathrm{Ci} / 100 \mu \mathrm{l})$ was added to each well without change of media. Twenty-four hours later plates were frozen at $-20^{\circ} \mathrm{C}$ until further processing. For determination of radioactivity incorporated into DNA, cultures were thawed and trypsinized, harvested by a multiple sample harvester on glass fiber filters and $\left[{ }^{3} \mathrm{H}\right]$-incorporation was determined by liquid scintillation counting in a Packard counter.

Initially, cell counts were determined also at the beginning and 2 days after respective experiments in microtiter plates to verify linear correlation between cell numbers and incorporation of radiolabel. $\left[{ }^{3} \mathrm{H}\right]$-Thymidine incubation of cells for $24 \mathrm{hr}$ was in no way harmful nor led to any cell loss, although no carrier thymidine was added. The presence of sera in all experiments likely has a protective effect.

\section{Demonstration of Nucleoside Diphosphatase (NDPase)- and Thiamine-Pyrophosphatase (TPPase)-Activity}

NDPase- and TPPase-activity were demonstrated in microglial cells cultured on glass slides that were coated with poly-D-lysine $(50 \mu \mathrm{g}$ poly-D-lysine $/ \mathrm{ml})$ according to the method of Novikoff and Goldfischer (1961) as modified by Murabe and Sano (1982) and Schnitzer (1989). Briefly, cell cultures were washed in phosphate buffered saline (PBS, pH 7.2), fixed for $4 \mathrm{hr}$ at $4{ }^{\circ} \mathrm{C}$ in $4 \%$ paraformaldehyde in $0.1 \mathrm{M}$ cacodylate buffer (pH 7.2) containing 8\% sucrose and 5\% dimethylsulfoxide (DMSO). Then cultures were extensively washed at $4^{\circ} \mathrm{C}$ in $0.1 \mathrm{M}$ cacodylate buffer ( $\mathrm{pH} 7.2$ ) containing $8 \%$ sucrose and transferred in $0.2 \mathrm{M}$ Tris-maleat buffer ( $\mathrm{pH} 7.2$ ) containing $8 \%$ sucrose. Subsequently, cultures were incubated for $15 \mathrm{~min}$ at $37^{\circ} \mathrm{C}$ in the following medium: distilled $\mathrm{H}_{2} \mathrm{O}(0.35 \mathrm{ml}), 0.2 \mathrm{M}$ Trismaleat buffer ( $\mathrm{pH} 7.2 ; 2 \mathrm{ml}), 1 \%$ lead citrate $(0.6 \mathrm{ml}), 25$ $\mathrm{mM}$ manganese chloride $(1 \mathrm{ml}), \mathrm{DMSO}(5 \mu \mathrm{l})$, and 10 $\mathrm{mM}$ inosine diphosphate $(1 \mathrm{ml})$ or $10 \mathrm{mM}$ TPP $(1 \mathrm{ml})$, respectively. After incubation, cultures were washed in distilled water, immersed in $2 \%$ aqueous ammoniumsul- 

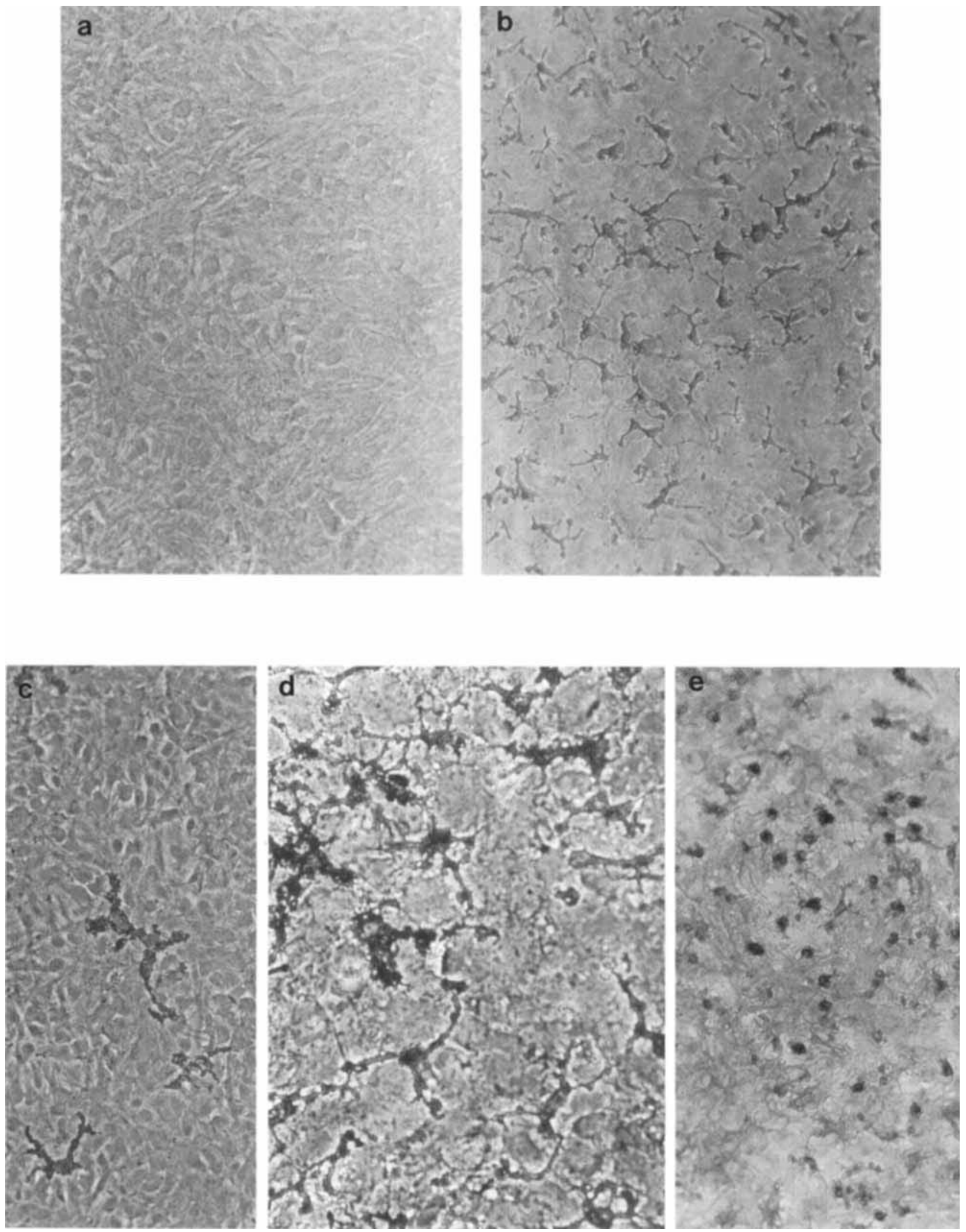

Fig. 1. Identification of microglia in mixed astrocyte/microglia cultures. Control (a), NDPase

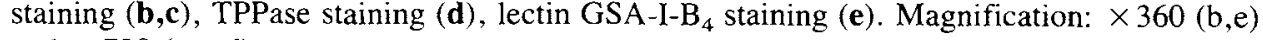
and $\times 720(a, c, d)$. 


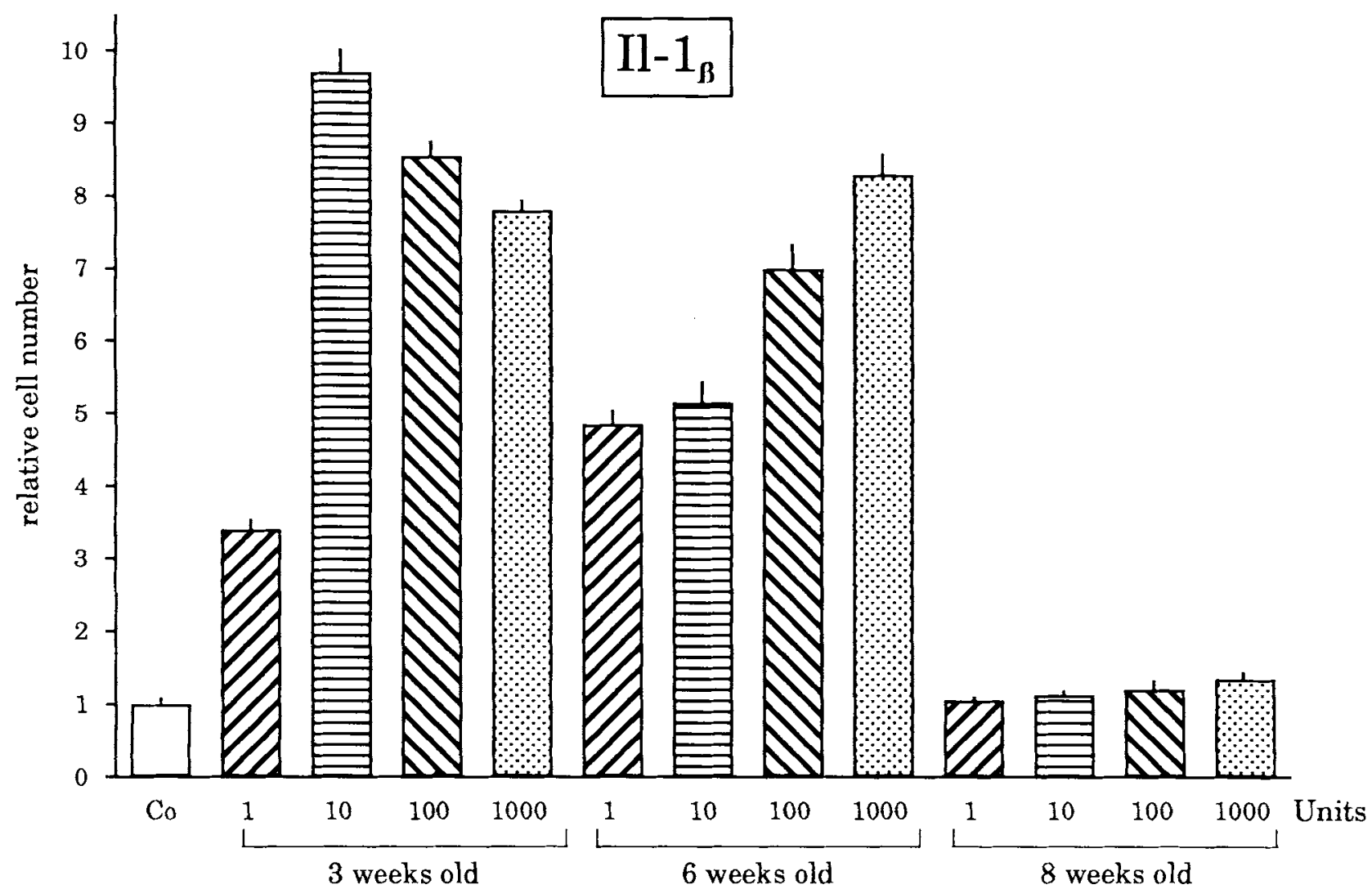

Fig. 2. Effect of $11-1_{\beta}$ on proliferation of microglia in mixed cultures. Mitogenic activity of $1,10,100$, and 1,000 Units $/ \mathrm{ml}$ of recombinant human $1 \mathrm{l}-1_{\beta}$ was determined by counting microglia harvested from mixed cultures $(3,6$, or 8 weeks old). Data are means of at least 8 experiments. Typical cell numbers

fide solution for $1 \mathrm{~min}$, washed again in $\mathrm{H}_{2} \mathrm{O}$, and viewed with a Zeiss microscope.

\section{Lectin Staining of Microglia by Using the Lectin GSA-I-B 4}

Staining of microglia by using the lectin GSA-I- $\mathrm{B}_{4}$ was carried out according to Streit et al. (1990). Microglial cells were cultured on poly-D-lysine coated coverslips in $35 \mathrm{~mm}$ culture dishes $\left(10^{6}\right.$ cells/dish). Cultures were washed in phosphate buffered saline (PBS, pH 7.2), fixed for $4 \mathrm{hr}$ at $4^{\circ} \mathrm{C}$ in $4 \%$ paraformaldehyde in 0.1 M PBS (pH 7.2) and thoroughly washed in 0.1 M PBS containing $0.1 \%$ Triton $\mathrm{X}-100$. Then cells were incubated overnight at $4^{\circ} \mathrm{C}$ in $0.1 \mathrm{M}$ PBS containing $0.1 \%$

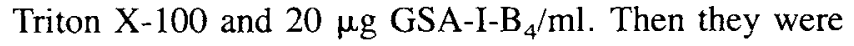
washed in 0.1 M PBS and stained according to standard procedures using 3,3'-diaminobenzidine and $\mathrm{H}_{2} \mathrm{O}_{2}$ as substrates for peroxidase reaction.

\section{Preparation of Conditioned Media}

Astrocyte cultures were prepared as described above. Three-week-old cultures were washed in DMEM were 190 cells/well in controls, 660 cells/well at $1 \mathrm{U} \mathrm{Il}-1 / \mathrm{ml}$, 1,790 cells/well at $10 \mathrm{U} \mathrm{II-1/ml} \mathrm{harvested} \mathrm{from} 3$-week-old cultures. Controls and Il-1 treated cultures were of the same age. All values of stimulated 3- or 6-week-old cultures are significantly different from values of controls $(P<0.05)$.

(serum free) and cultured for $24 \mathrm{hr}$ in DMEM supplemented with 5\% FCS (ACM). Microglia conditioned media (MiCM) were prepared from microglia plated into $100 \mathrm{~mm}$ culture dishes and cultured for $6 \mathrm{hr}$ in DMEM supplemented with $5 \%$ FCS. Supernatants were harvested and stored at $-20^{\circ} \mathrm{C}$ until use.

\section{Il-1, Il-6, and ' NFF $_{\alpha}$ Bioassays}

Il-1, Il-6, and $\mathrm{TNF}_{\alpha}$ were determined in media conditioned by isolated microglia in the presence or absence of LPS or glucocorticoids. Il-1 was measured according to Northoff et al. $(1986 \mathrm{a}, \mathrm{b})$ using the $\mathrm{C} 3 \mathrm{H} / \mathrm{HeJ}$ mouse cell line, Il-6 was measured using the 7TD1 cell line, and $\mathrm{TNF}_{\alpha}$ was determined using the L929 mouse fibrosarcoma cell line (Männel et al., 1989).

\section{RESULTS \\ Identification of Microglial Cells in Astroglial Cultures}

Various staining procedures for microglia have been described. ED 1 staining has been routinely per- 


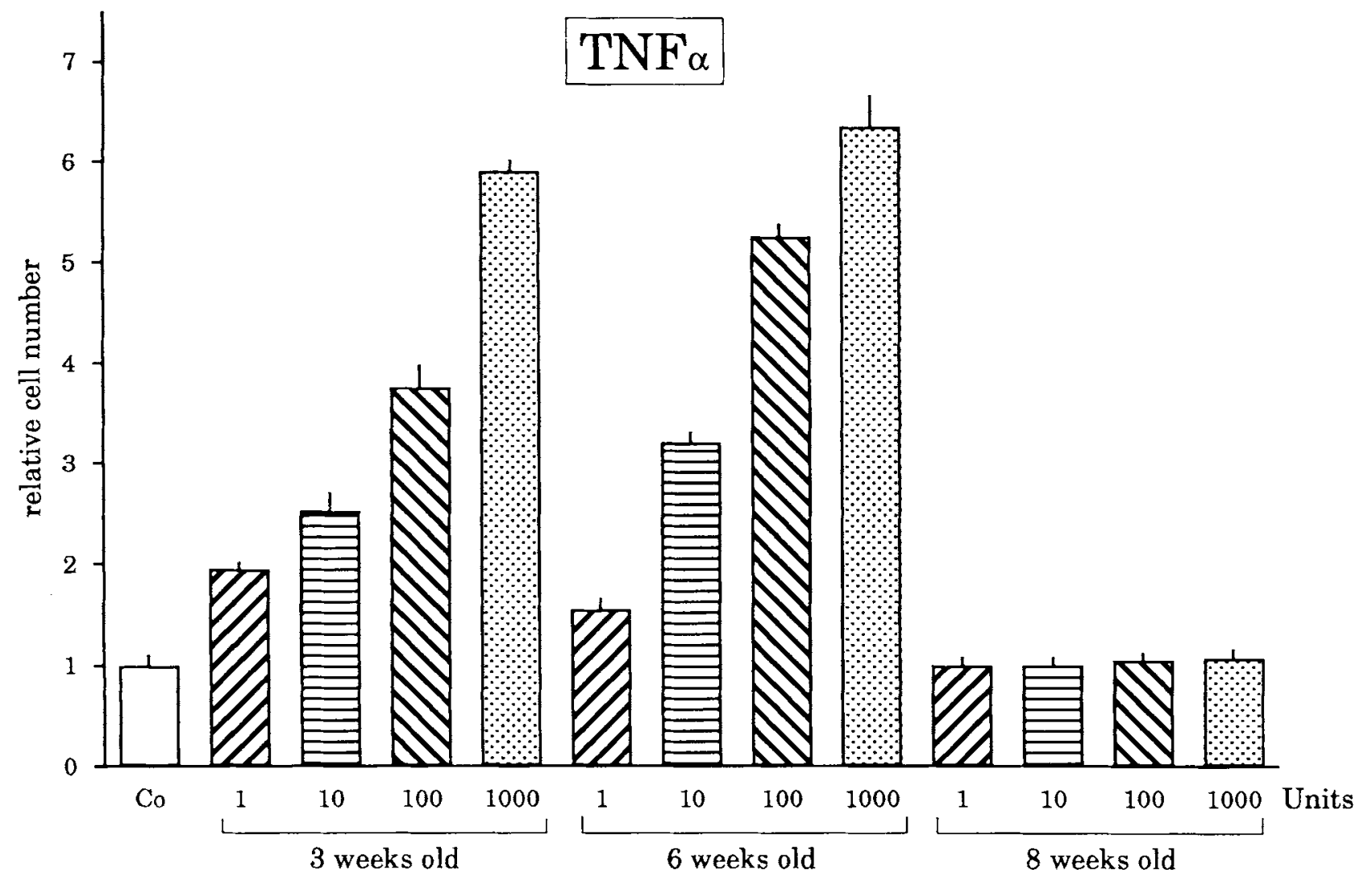

Fig. 3. Effect of $\mathrm{TNF}_{\alpha}$ on proliferation of microglia in mixed cultures. Microglial cell numbers were determined after collection from mixed cultures $(3,6$, or 8 weeks old) cultured in the presence of $1,10,100$, and 1,000 Units $/ \mathrm{ml}$ of recombinant human $\mathrm{TNF}_{\alpha}$. Typical cell numbers were $190 \mathrm{cells} / \mathrm{well}$ in controls, 360 cells/well at $1 \mathrm{U} \mathrm{TNF}_{\alpha} / \mathrm{ml}, 1,280$ cells/well at

$1000 \mathrm{U} \mathrm{TNF}_{\alpha} / \mathrm{ml}$ harvested from 3-week-old cultures. Controls and $\mathrm{TNF}_{\alpha}$ treated cultures were of the same age. Data are means of at least 8 experiments. All values of stimulated 3- or 6-week-old cultures are significantly different from values of controls $(P<0.05)$.

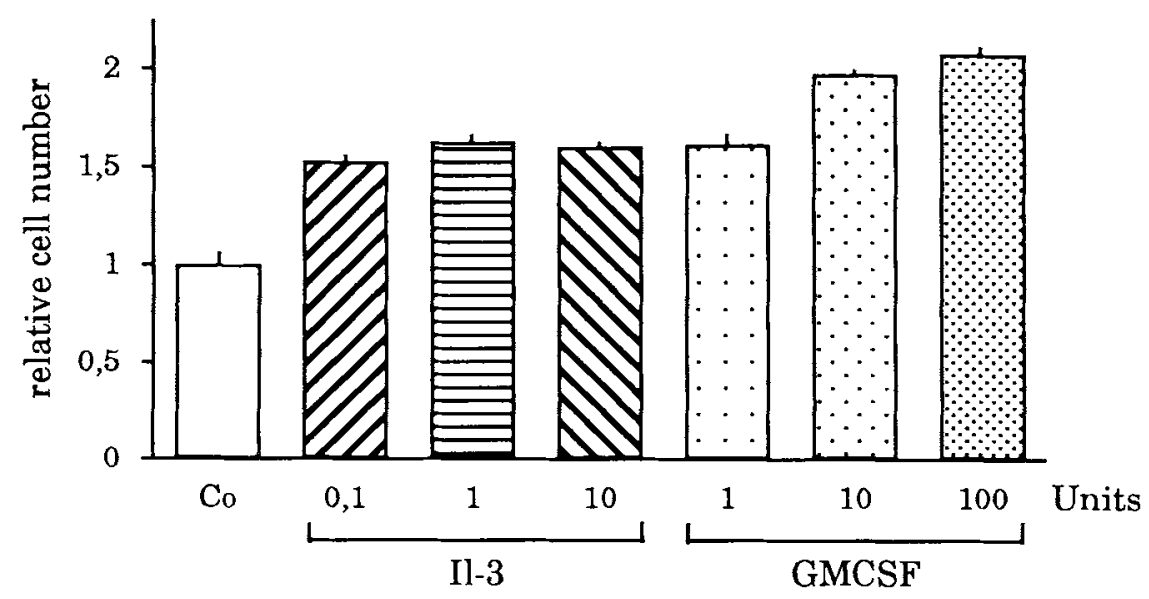

Fig. 4. Effect of II-3 and GMCSF on proliferation of microglia in mixed cultures. Mitogenic activity of $0.1,1$, and $10 \mathrm{U} / \mathrm{ml}$ of recombinant murine $11-3$ and of 1,10 , and $100 \mathrm{U} / \mathrm{ml}$ of murine GMCSF was determined in 3-week-old mixed cultures as described in Methods and Figures 2/3. Typical cell numbers were

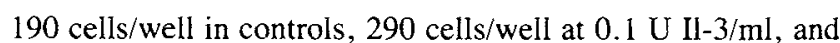
390 cells/well at $100 \mathrm{U} \mathrm{GMSCF} / \mathrm{ml}$. Data are means of at least six experiments. All stimulated values are significantly different from controls $(P<0.05)$. 


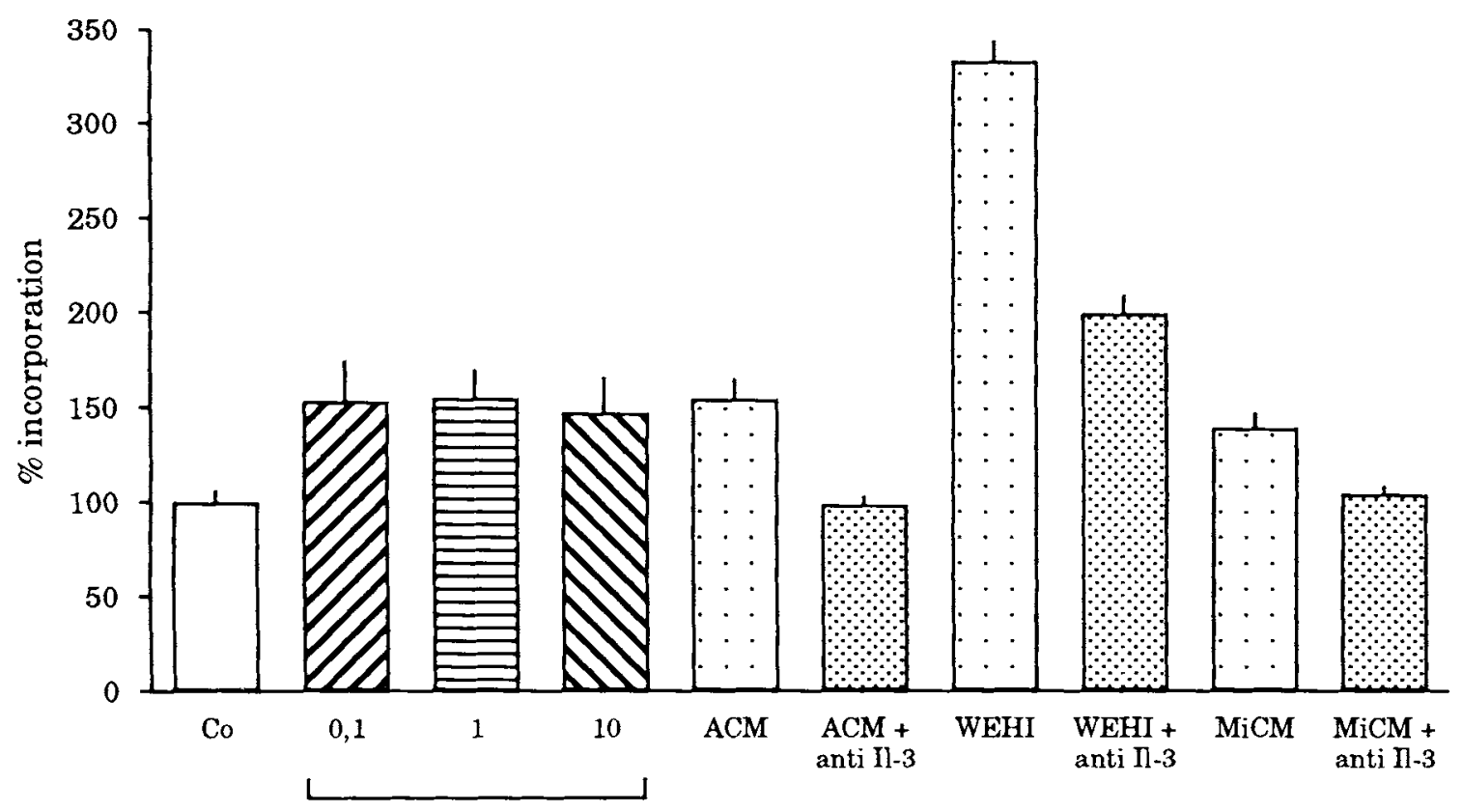

Units II-3

Fig. 5. Effect of 1l-3, astrocyte conditioned media (ACM), WEHI-2B supernatants (WEHI), and microglia conditioned media (MiCM) on $\left[{ }^{3} \mathrm{H}\right]$-thymidine incorporation into isolated microglia. $0.1,1$, and $10 \mathrm{U} / \mathrm{ml}$ recombinant murine $1 \mathrm{l}-3$ were used. ACM and WEHI CMs were diluted 1:4 with DMEM supplemented with $5 \%$ fetal calf serum; MiCM was diluted 1:3 with DMEM supplemented with $5 \%$ fetal calf serum. A linear relationship between increase in cell number and $\left[{ }^{3} \mathrm{H}\right]$-thymidine incorporation had been evaluated before beginning of ex-

formed in our laboratory (Gebicke-Härter et al., 1989). Microglia can also be visualized in mixed astrocyte/microglia cultures by NDPase-, and TPPase-, and lectinstaining as shown in Figure 1. Proliferating microglia typically sitting atop the astrocytic layer or floating in the media were removed by the staining procedure. Remaining microglia, inserted between astrocytes, morphologically resembled resting ramified cells. Since comparable cells were found in isolated cultures, it is hypothesized that proliferating (round) cells derive from ramified cells and round cells are able to transform into ramified cells.

\section{II-1, TNF, Il-3, and GMCSF Stimulate Microglial Proliferation in Mixed Astroglial-Microglial Cultures}

Recombinant Il- 1 increased the number of floating microglia in mixed cultures 2 -9.7-fold above controls (Fig. 2). Three and 6-week-old cultures showed a concentration-dependent increase in cell numbers, whereas in older cultures ( 8 weeks old) no more mitogenic effect was observed. Two- to 6.3-fold increases in cell number were determined in cultures grown in the presence of periments. Typically, the cells incorporated $2,650 \mathrm{cpm} / \mathrm{well}$ in controls and 9,200 cpm/well in WEHI-CM-treated microglia. The mitogenic activity was determined in the absence and in the presence $(+$ anti Il-3) of a specific anti-Il-3 antibody. Adding antibodies to control cells had no effect. Data are means of at least eight experiments. All but antibody treated values were significantly different from controls $(P<0.05)$. Values of antibody treated cultures are significantly different from values of untreated cultures $(P<0.05)$.

$\mathrm{TNF}_{\alpha}$ (Fig. 3). Microglia in younger cultures (3 and 6 weeks old) showed a significant increase in their proliferation rate upon TNF-treatment, whereas older cultures ( 8 weeks old) no longer responded to TNF with increased cell division. Moreover, Il-3 and GMCSF increased the number of floating microglia in mixed cultures $(1,5$ 1,6-fold and 1,6-2,1-fold above controls, respectively) (Fig. 4).

\section{Mitogenic Effect of Il-1, TNF, II-3, and GMCSF on Purified Microglia}

II- 1 and TNF had no significant effects on $\left[{ }^{3} \mathrm{H}\right]-$ thymidine incorporation into isolated microglia independent of media (DMEM supplemented with 5\% FCS, astrocyte conditioned media or WEHI supernatant). Furthermore, combinations of Il-1 with TNF, II-3, or GMCSF or combinations of TNF with Il-1, Il-3, or GMCSF had no synergistic or additive effects on $\left[{ }^{3} \mathrm{H}\right]-$ thymidine incorporation, whatsoever (data not shown). Il-3, however, stimulated incorporation of $\left[{ }^{3} \mathrm{H}\right]$-thymidine (approximately 1.6-fold). The mitogenic effect was not concentration-dependent (tested in the range from 


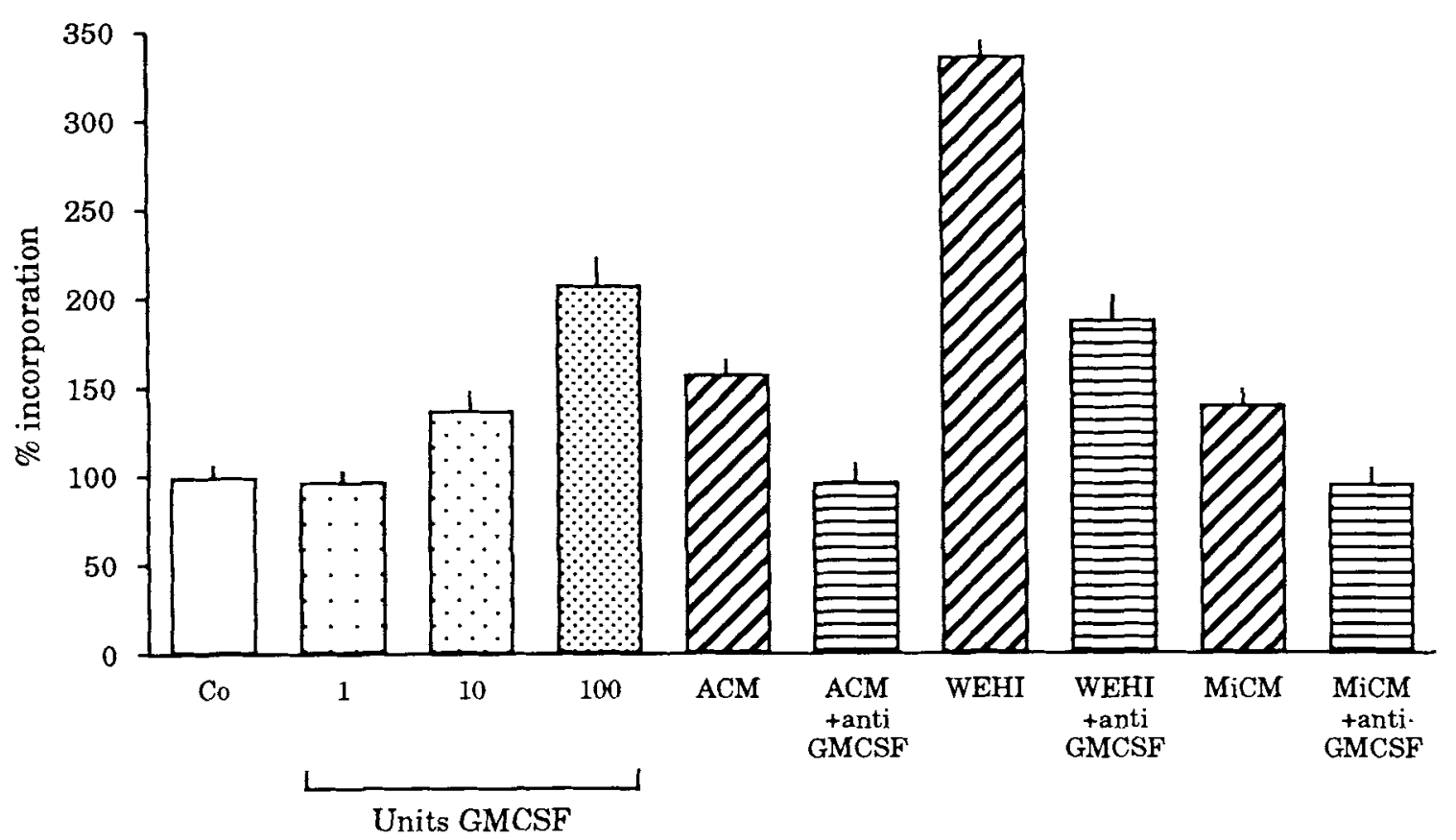

Fig. 6. Effect of GMCSF, astrocyte conditioned media (ACM), WEHI supernatant (WEHI), and microglia conditioned media (MiCM) on $\left[{ }^{3} \mathrm{H}\right]$-thymidine incorporation into isolated microglia. $1.0,10$, and $100 \mathrm{U} / \mathrm{ml}$ recombinant murine GMCSF were used. ACM and WEHI CMs were diluted 1:4 with DMEM supplemented with 5\% fetal calf serum; MiCM was diluted 1:3 with DMEM supplemented with 5\% fetal calf serum. A linear relationship between increase in cell number and $\left[{ }^{3} \mathrm{H}\right]$-thymidine incorporation had been evaluated before beginning of experiments. Typically the cells incorporated $2,650 \mathrm{cpm} /$ well in controls and $9,200 \mathrm{cpm} /$ well in WEHI

0.1 to $10 \mathrm{U} / \mathrm{ml}$ ) (Fig. 5). Combinations of $11-3$ with GMCSF showed no synergistic or additive effects (data not shown). Incubation of isolated microglia with WEHI supernatants resulted in marked increases of $\left[{ }^{3} \mathrm{H}\right]$-thymidine incorporation. This effect could be partially abolished by adding anti-I1-3 antibodies (purified IgGs) (Fig. 5). The mitogenic effects of astrocyte (ACM) and microglia (MiCM) conditioned media could be abolished by these antibodies (Fig. 5).

Furthermore, GMCSF stimulated microglial proliferation in an dose dependent manner as shown by $\left[{ }^{3} \mathrm{H}\right]-$ thymidine incorporation. The maximal stimulation was 2-fold above control cultures (Fig. 6).

As shown above, separated microglia showed an increased incorporation of $\left[{ }^{3} \mathrm{H}\right]$-thymidine when cultured in WEHI supernatant, astrocyte conditioned media and microglia conditioned media. These effects could be partially or totally abolished by anti-GMCSF antibodies (purified IgGs) (Fig. 6).
CM-treated microglia. The effects on thymidine incorporation were tested in the absence and in the presence ( + antiGMCSF) of a specific anti-GMCSF antibody (purified IgG from rabbit polyclonal antisera). Data are means of at least eight experiments. Values obtained from ACM and MiCM supplemented with anti-GMCSF as well as values obtained from microglia treated with $1 \mathrm{U}$ recombinant GMCSF were not different from controls. All inhibitory effects of anti-GMCSF antibodies were significant compared to respective stimulated values $(P<0.05)$.

\section{LPS Inhibits $\left[{ }^{3} \mathrm{H}\right]$-Thymidine Incorporation}

Maintenance of mixed cultures with LPS resulted in a concentration dependent decline of protein content. As shown in earlier investigations, this was due to an inhibition of microglial proliferation (Gebicke-Härter et al., 1989). Proliferation of isolated microglia was also inhibited by LPS in a concentration dependent manner (Fig. 7). A total of $10^{-9} \mathrm{~g} \mathrm{LPS} / \mathrm{ml}$ diminished $\left[{ }^{3} \mathrm{H}\right]-$ thymidine incorporation by more than $90 \%$. At a concentration of $10^{-15} \mathrm{~g} \mathrm{LPS} / \mathrm{ml}$ no more inhibition was observed (Fig. 7). Furthermore, LPS $\left[10^{-7} \mathrm{~g} / \mathrm{ml}\right]$ added to DMEM supplemented with 5\% FCS, to astrocyte conditioned media, WEHI supernatant, microglia conditioned media or media containing Il-3 or GMCSF, inhibited proliferation of isolated microglia by more than 90\% (Fig. 8). In mixed cultures incubated with LPS during the first 3 days of culture, no proliferation of microglia was observed during the whole culture time. 


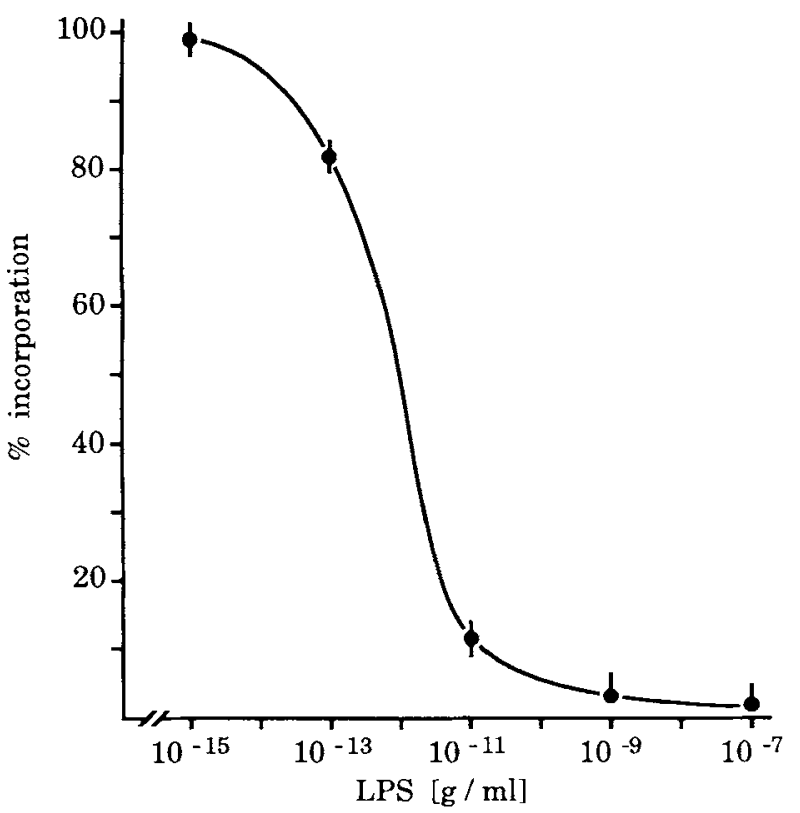

Fig. 7. Concentration dependent effect of LPS on proliferation of isolated microglia. The experiments were carried out in DMEM supplemented with $5 \%$ fetal calf serum. The inhibitory effect of LPS on thymidine incorporation was tested in the range of $10^{-7}$ to $10^{-15} \mathrm{~g} / \mathrm{ml}$. Data are means of at least eight experiments.

These cultures were in no way different from cultures treated with LPS throughout culture time (data not shown).

\section{Effect of Steroids on [ $\left.{ }^{3} \mathrm{H}\right]$-Thymidine Incorporation}

Progesterone and aldosterone added to separated microglial cells inhibited cellular proliferation in a concentration dependent manner between $10^{-4} \mathrm{M}$ and $10^{-9} \mathrm{M}$ (Fig. 9). Inhibitory effects of the glucocorticoids hydrocortisone and dexamethasone were obtained in the concentration range of $10^{-8} \mathrm{M}$ to $10^{-11} \mathrm{M}$. At lower concentrations, these hormones showed a significant stimulatory effect on microglial proliferation (Fig. 9). The inhibitory effect of progesterone could be abolished by the progesterone receptor antagonist RU 38486 (Fig. 10). Similarly the effects of dexamethasone and hydrocortisone were antagonized by RU 38486 . RU 38486 by itself had no effect on proliferation of microglia (Fig. $10)$.

No significant changes of microglial proliferation were observed upon incubation of isolated cells with estradiol $\left(10^{-6} \mathrm{M}\right.$ to $\left.10^{-14} \mathrm{M}\right)$ (data not shown).

\section{Effect of Corticosteroids on Proliferation of Microglia in Mixed Astroglial-Microglial Cultures}

When mixed cultures were incubated with dexamethasone $\left[10^{-7} \mathrm{M}\right]$ or hydrocortisone $\left[10^{-7} \mathrm{M}\right]$ during the first 3 days of the culture period microglial cell numbers, counted after 4 weeks, were diminished significantly ( $80 \%$ or $55 \%$, respectively). RU 38486 antagonized this effect while having no effect on proliferation of microglia by itself. Addition of dexamethasone or hydrocortisone during the whole culture time resulted in a reduction of cell counts by $93 \%$ or $61 \%$, respectively. This effect could be abolished by RU 38486 as well (Fig. 11). In contrast, progesterone and estradiol showed no effects on proliferation of microglia when added to mixed cultures for 3 days or for the whole period of culture (data not shown).

\section{Corticosteroids Inhibit LPS-Stimulated Production of Microglial Il-1, Il-6, and TNF}

Isolated microglia were treated with LPS, dexamethasone, or a combination of both for a total of $24 \mathrm{hr}$. The steroid hormone was given before, at the same time, or at a delay of $6 \mathrm{hr}$ after LPS. As shown previously, LPS by itself induced synthesis of Il-1, Il-6, and $\mathrm{TNF}_{\alpha}$ in microglia (Fig. 12, control bar at bottom). Dexamethasone inhibits production of these cytokines when added before or simultaneously with LPS. Incubation with dexamethasone at a delay of $6 \mathrm{hr}$ after LPS diminished cytokine production significantly.

\section{DISCUSSION}

One of the salient features of microglia, in contrast to monocytes, is their capacity to proliferate in response to any kind of brain injury or disease. The study of factors with potential effects on this response remained elusive until the establishment of highly enriched or pure microglial cultures. In this study it is shown that some proinflammatory cytokines in association with as yet unidentified astroglial factors are able to upregulate microglial proliferation. The findings that Il-1 and TNF were potent mitogens when added to mixed cultures but did not increase proliferation in isolated cultures is good indication for additional factors produced in astroglial cultures. The nature of these factors remains obscure. They may be synthesized constitutively or may be induced by Il-1 or $\mathrm{TNF}_{\alpha}$. Il-6 is not a likely candidate since it did not synergize with Il-1 or $\mathrm{TNF}_{\alpha}$ in isolated microglial cultures. Furthermore, synergistic or additive effects of Il-1 with $\mathrm{TNF}_{\alpha}$, Il-3, or GMCSF and of $\mathrm{TNF}_{\alpha}$ with Il-1, Il-3, or GMCSF were not found. These results imply an important regulatory role of other astroglial factors for microglial proliferation.

It has been shown elsewhere (Frei et al., 1986; Giulian and Ingeman, 1988) that GMCSF and Il-3 are mitogens for microglia. These findings may be somewhat surprising in the light of the fact that recombinant murine polypeptides were used in each case. Both on the 


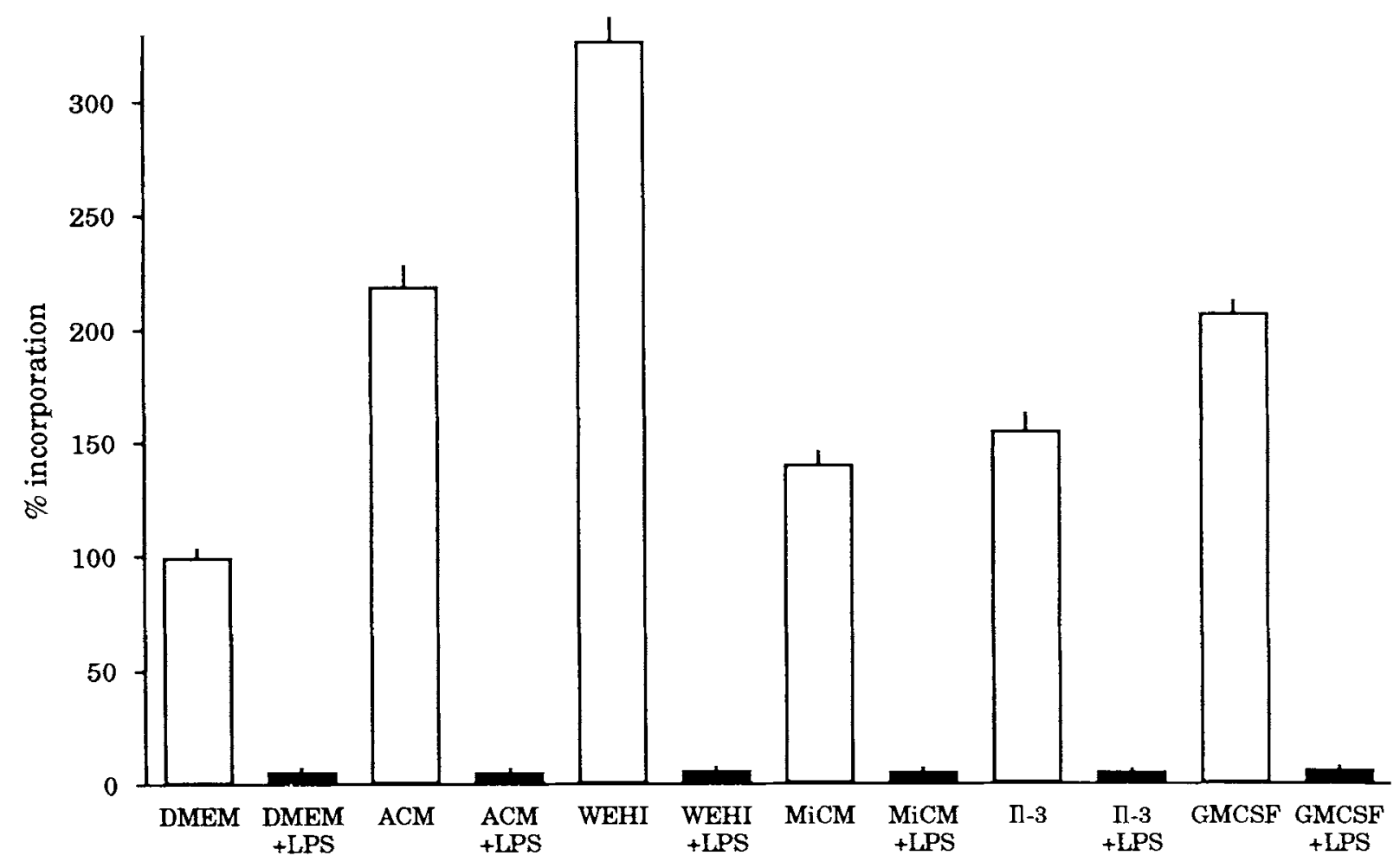

Fig. 8. Effect of LPS on $\left[{ }^{3} \mathrm{H}\right]$-thymidine incorporation into isolated microglia induced by various stimuli. ACM and WEHI CMs were diluted 1:4 with DMEM supplemented with 5\% fetal calf serum; MiCM was diluted 1:3 with DMEM supplemented with $5 \%$ fetal calf serum. Il-3: $10 \mathrm{U}$ of Il-3/ml DMEM supplemented with $5 \%$ fetal calf serum. GMCSF: $100 \mathrm{U}$ of

amino acid and on the nucleotide level, the murine and rat sequences of GMCSF and Il-3 differ markedly, which gives rise to the statement that "murine Il-3 is not biologically active in assays for rat or human Il-3" (Ihle et al., 1990). We speculate that the recombinant factors most likely bind to but have only moderate effects on rat cells. Additionally, Il-3 may-to some extent-react with the GMCSF receptor and GMCSF with the Il-3 receptor. The active component in $\mathrm{CMs}$, therefore, is difficult to identify. We and others have confirmed, however, that the WEHI-2B cell line does not produce GMCSF. The microglial response to WEHI CM, thus, is due to the presence of murine Il-3. It would be of great help to have the respective rat cytokines and antibodies available. Moreover, it would be desirable to have antisera that specifically recognize Il-3 or GMCSF. Apparently, GMCSF antibodies used in the present studies also inhibited Il-3 effects. It is possible that these antibodies are more specific in the mouse. Altogether, we conclude that the two principal growth factors for microglia present in astrocyte and microglia CMs are GMCSF and Il-3. These two cytokines appear to be direct microglial
GMCSF/ml DMEM supplemented with $5 \%$ fetal calf serum. The experiments were carried out in the absence and the presence ( + LPS) of $5 \mathrm{ng} / \mathrm{ml}$ LPS. Data are means of at least eight experiments. All values of LPS-treated cultures are significantly different from values of untreated cultures $(P<0.05)$.

mitogens since they are the only factors tested here that elicit mitogenic signals both in mixed and in isolated cultures. Microglia are strong candidates as a source for Il-3 production, as shown previously (Gebicke-Härter et al., 1990). These observations support the idea that astrocytes produce growth factors for microglia but also that microglia can synthesize and secrete their own growth factors.

It is shown here that a number of corticosteroids are potent inhibitors of microglial proliferation. These substances are able to modulate the expression of a great variety of genes (Schena and Yamamoto 1988; Hadcock and Malbon, 1988; Seitz et al., 1991; Gupta et al., 1991) including genes for growth factors and specific receptors for growth factors (Papa et al., 1990; Djaldetti et al., 1990; Nishida et al., 1989; Polan et al., 1989; Pryjma et al., 1989; Tobler et al., 1991). In contrast to the effect of LPS, corticosteroids apparently do not drive microglia into more differentiated states but rather "freeze" the cells in their actual stages of maturation (Hatakeyama et al., 1990).

Steroids can pass the blood-brain barrier and the 


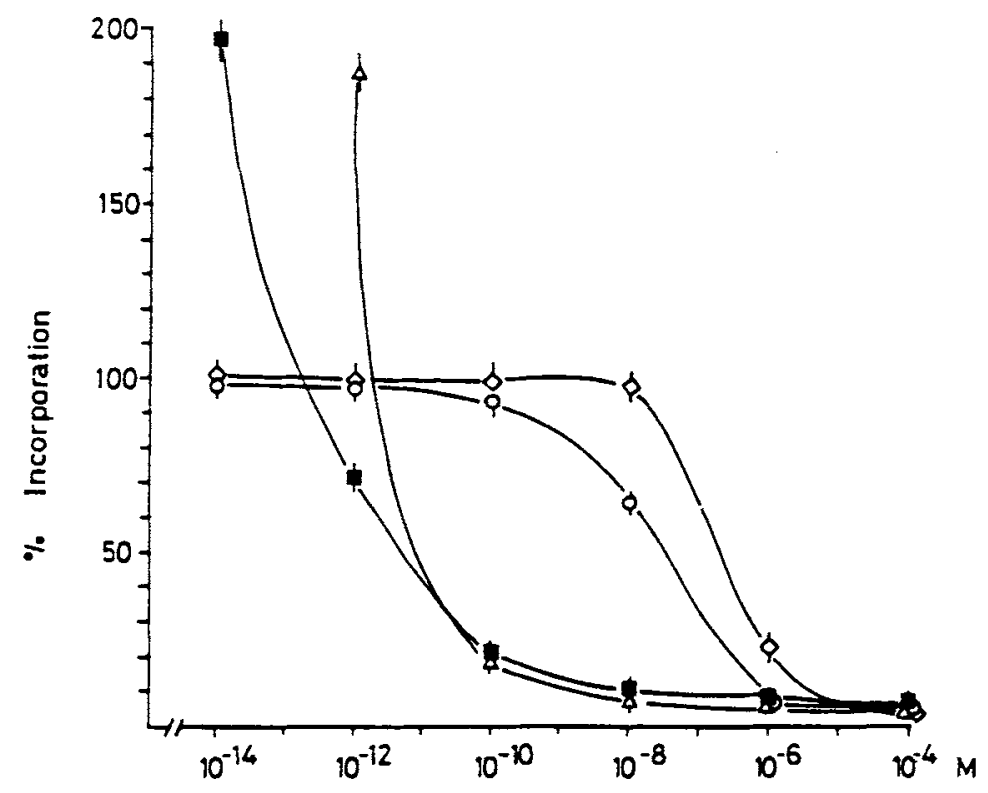

Fig. 9. Concentration dependent effect of progesterone $(\diamond)$, dexamethasone $(\triangle)$, hydrocortisone (匹), and aldosterone $(O)$ on $\left[{ }^{3} \mathrm{H}\right]$-thymidine incorporation into isolated microglia. All experiments were carried out in DMEM supplemented with $5 \%$ fetal calf serum. Data are means of at least eight experiments.

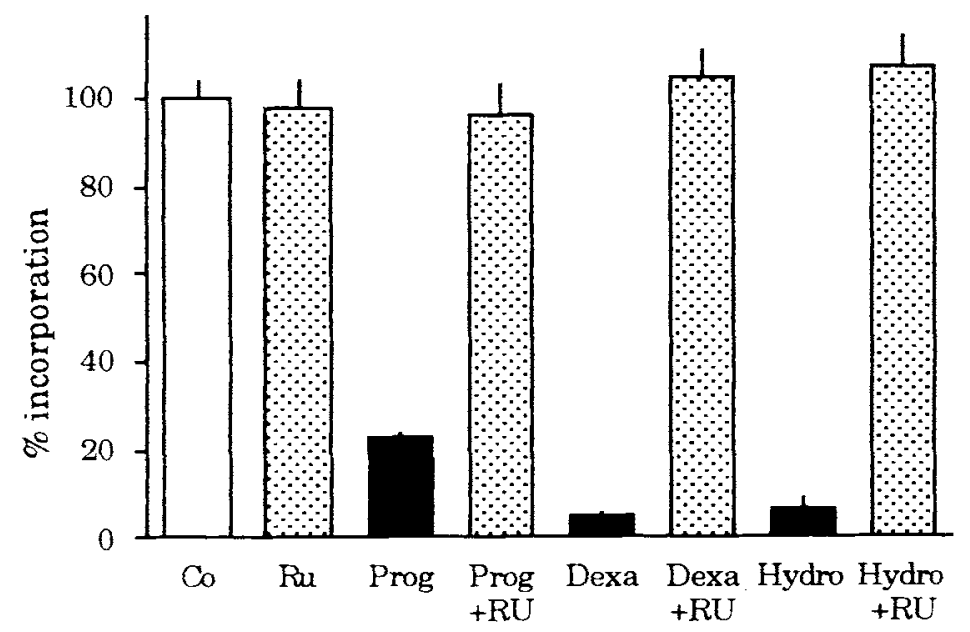

Fig. 10. Effects of progesterone $\left(10^{-6} \mathrm{M}\right)$, dexamethasone $\left(10^{-9} \mathrm{M}\right)$, and hydrocortisone $\left(10^{-9} \mathrm{M}\right)$ on $\left[{ }^{3} \mathrm{H}\right]$-thymidine incorporation into isolated microglia. Effects of steroids were tested in DMEM supplemented with $5 \%$ fetal calf serum in the

plasma membrane of cells because of their hydrophobicity. The glucocorticoids, in particular, feed back to the hypothalamus and pituitary as regulatory elements of the HPA axis. Normal glucocorticoid levels may well exert a persistent inhibitory tonus on microglial proliferation. Local tissue damage (cell death, myelin degradation), however, may elicit inflammatory events that eventually overcome this inhibition. In keeping with this line of absence and the presence of $10^{-4} \mathrm{~g} / \mathrm{L}$ RU 38486 (+ RU). Data are means of at least eight experiments. Values of steroidtreated cultures are significantly different from values of untreated cultures $(P<0.05)$.

reasoning, it is feasible that stress-dependent enhancement of glucocorticoid levels results in suppression of the microglial reaction and, subsequently, in impaired immunoreactivity of microglia.

In contrast to the corticosteroids, which appear to inhibit microglial proliferation by some fine-tuned, reversible mechanism, LPS as a proinflammatory substance irreversibly turns off microglial proliferation. The 


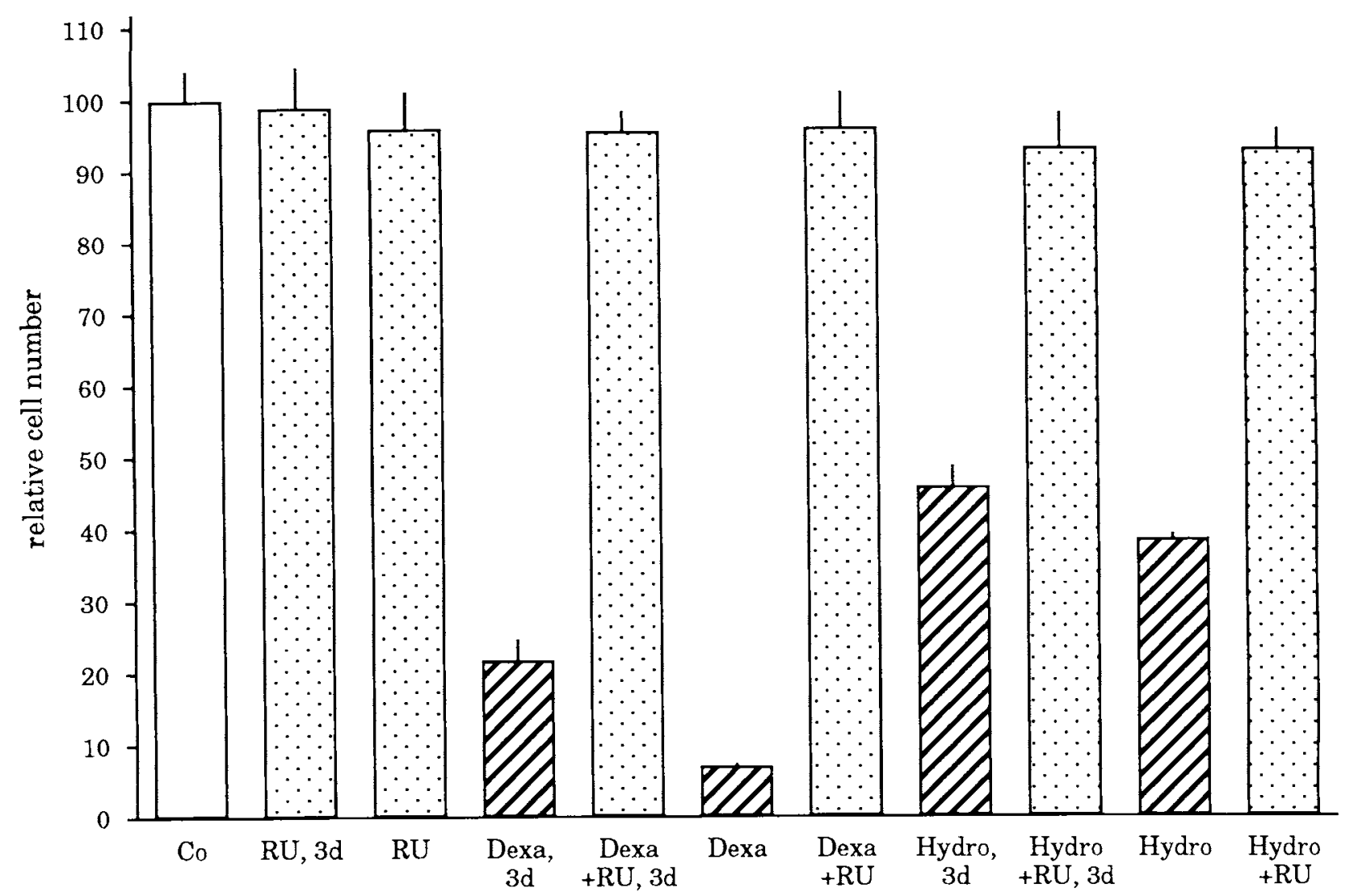

Fig. 11. Effect of dexamethasone $\left(10^{-7} \mathrm{M}\right)$ and hydrocortisone $\left(10^{-7} \mathrm{M}\right)$ was determined by counting microglia harvested from mixed cultures. Cultures were incubated with the steroids or steroids and RU $38486\left(10^{-4} \mathrm{~g} / \mathrm{L}[+\mathrm{RU}]\right)$ for the

first 3 days ( $3 d$ ) or for the whole period of culture (4 weeks). The data shown are means of at least six experiments. Values of steroid-treated cultures are significantly different from values of untreated cultures $(P<0.05)$.

Dex. $\left(5 \times 10^{-7} \mathrm{M}\right)$

LPS $(500 \mathrm{ng} / \mathrm{ml})$

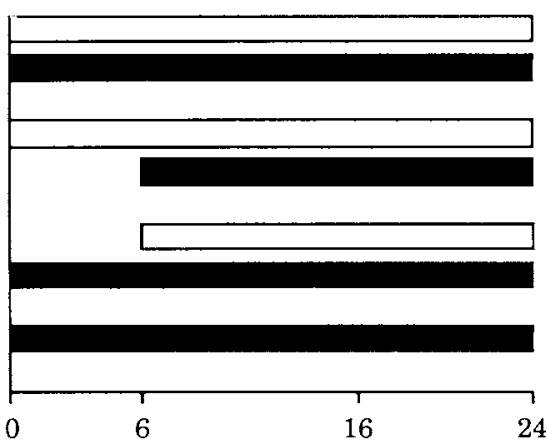

$24 \mathrm{t}(\mathrm{h})$

\begin{tabular}{ccc}
$\begin{array}{c}\text { II-1 } \\
(\mathrm{U} / \mathrm{ml})\end{array}$ & $\begin{array}{c}\mathrm{Il-6} \\
(\mathrm{U} / \mathrm{ml})\end{array}$ & $\begin{array}{c}\mathrm{TNF} \\
(\mathrm{ng} / \mathrm{ml})\end{array}$ \\
\hline 0 & 55 & $<0,3$ \\
\hline 0 & 25 & $<0,3$ \\
\hline 15 & 210 & 1,25 \\
\hline$>100$ & 448 & 2,5 \\
\hline
\end{tabular}

Fig. 12. Effect of dexamethasone on LPS-induced cytokine production in isolated microglia. LPS-induced Il-1, Il-6, and $\mathrm{TNF}_{\alpha}$-synthesis (bar at bottom) were markedly suppressed when steroid was given simultaneously with (two bars at top) or before addition of LPS (second two bars). Cytokine synthesis was significantly reduced upon delayed addition of dexamethasone ( 6 hr after LPS). Number of experiments: three times in triplicate each condition. 
cells differentiate to more mature macrophages and are no longer able to proliferate but become phagocytic and secrete cytotoxins, growth factors, and other mediators of inflammation. The production of Il-1, Il-6, and $\mathrm{TNF}_{\alpha}$ obviously is under the control of glucocorticoids both in macrophages and in microglia. Apparently, glucocorticoids exert their influences on various levels of microglial cell activation. In summary, the present data strongly support the notion that astrocytes synthesize and secrete growth factors for microglia. Therefore, the regulation of microglial growth is highly dependent from the state of activation of astrocytes. Microglia, in turn, may respond with secretion of their own growth factors. Our data, moreover, identify corticosteroids as potent inhibitors of microglial proliferation. The cell culture systems described here appear to be very valuable for controlled studies on molecular mechanisms of inflammatory events as observed in injured brain in vivo.

\section{ACKNOWLEDGMENTS}

We want to express our gratitude to Dr. I. Rich and to Dr. de LaMarter for supply of WEHI-2B CMs and anti-Il-3/GMCSF antisera, respectively. The expert technical assistance of Ms. A. Schobert, R. Heldt, and Mr. Lay is greatly acknowledged. This study was supported by DFG grant Ge 486/2-1 (P.J. Gebicke-Härter.)

\section{REFERENCES}

Cammermeyer J (1970): The life history of the microglial cell: A light microscopic study. In Ehrenpreis S, Solnitzky OC (eds.): "Neurosciences Research." New York: Academic Press, vol 3, pp 44-129.

Djaldetti R, Fishman, Shtatlender V, Sredni B, Djaldetti M (1990): Effect of dexamethasone on Il-1 and Il-3-LA release by unstimulated human mononuclear cells. Biomed Pharmacother 44 (10):515-518.

Frei K, Bodmer S, Schwerdel C, Fontana A (1986): Astrocyte-derived interleukin 3 as a growth factor for microglial cells and peri toneal macrophages. J Immunol 137:3521-3527.

Gebicke-Härter PJ, Bauer J, Schobert A, Northoff H (1989): Lipopolysaccharide-free conditions in primary astrocyte cultures allow growth and isolation of microglial cells. J Neurosci $9(1)$ : $183-194$.

Gebicke-Härter PJ, Rich IN, Schobert A, Northoff H (1990): Regulation of microglial cytokine expression. 8th ISDN meeting, Bal Harbour, FL, \#78.

Giulian D, Baker TJ (1986): Characterization of ameboid microglia isolated from developing mammalian brain. J Neurosci $6(8)$ : 2163-2178.

Giulian D (1987): Ameboid microglia as effectors of inflammation in the central nervous system. J Neurosci Res 18:155-171.

Giulian D, Ingeman JE (1988): Colony-stimulating factors as promotors of ameboid microglia. J Neurosci 8(12):4707-4717.

Gupta MK, Arciaga R, Posch A (1991): Effect of estradiol and tamoxifen on IGF-I and IGF-I-receptor levels in human breast cancer cells. Faseb J 5(4):981, A540.
Hadcock JR, Malbon CC (1988): Regulation of $\beta$-adrenergic receptors by "permissive" hormones: glucocorticoids increase steady state levels of receptor mRNA. Proc Natl Acad Sci USA 85: 8415-8419.

Hatakeyama S, Suzuki A, Yoshizumi N, Sato M, Nishiya I (1990): Glucocorticoid-induced Gl arrest and the release effect of epidermal growth factor on the human salivary gland adenocarcinoma cell. Cell Biol Int Rep 15(1):55-65.

Hayes GM, Woodroofe MN, Cuzner ML (1988): Characterization of microglia isolated from adult human and rat brain. I Neuroimmunol 19:177-189.

Ihle JN (1990): Interleukin-3. In Born GVR, Cuatrecasas P and Herken H (eds.): "Handbook of Experimental Pharmacology." Berlin, Heidelberg, New York: Springer, vol 5/I, pp 541-575

Jordan FL, Thomas WE (1988): Brain macrophages: Questions of origin and interrelationship. Brain Res Rev 13:165-178.

Keller M, Jackisch R, Seregi A, and Hertting G (1985): Comparison of prostanoid forming capacity of neuronal and astroglial cells in primary cultures. Neurochem Int 7:655-665.

Kreutzberg GW and Barron ICD (1976): 5 ' nucleotidase of microglial cells in the facial nucleus during axonal reaction. $\mathrm{J}$ Neurocytol 7:601-610.

Ling EA, Paterson JA, Privat A, Mori S and Leblond CP (1973): Investigations of glial cells in semithin sections. I. Identification of glial cells in the brain of young rats. J Comp Neurol 149:43-72.

Ling EA (1981): The origin and nature of microglia. In Fedoroff $S$, Hertz L (eds): "Advances in Cellular Neurobiology." New York: Academic Press, 2:33-82.

Männel DN, Falk W (1989): Optimal induction of tumor necrosis factor production in human monocytes requires complete S-form lipopolysaccharide. Infect and Immun 57(7):19531958.

Mori S and Leblond CP (1969): Identification of microglia in light and electron microscopy. J Comp Neurol 135:57-80.

Murabe Y and Sano Y (1982): Morphological studies on neuroglia. V. Microglial cells in the cerebral cortex of the rat, with special reference to their possible involvement in synaptic function. Cell Tiss Res 223:493-506.

Nishida T, Nakai S, Kawakami T, Aihara K, Nishino N, Hirai $Y$ (1989): Dexamethasone regulation of the expression of cytokine mRNAs induced by interleukin- 1 in the astrocytoma cell line U373MG. FEBS Lett 243(1):25-29.

Northoff H, Kabelitz D and Galanos C (1986a): Interleukin 1 production for detection of bacterial polysaccharide in fetal calf sera and other solutions. Immunol Today 7:126-127.

Northoff H, Glück D, Wölpl A, Kubanek B and Galanos C (1986b): Lipopolysaccharide- induced elaboration of interleukin 1 (Il-1) by human monocytes: Use for the detection of LPS in serum and influence of serum-LPS interactions. Rev Infect Dis (Suppl.5) 9:599-602.

Novikoff AB and Goldfischer S (1961): Nucleosiddiphosphatase activity in the golgi apparatus and its usefulness for cytological studies. Proc Natl Acad Sci U.S.A. 47:802-810.

Oehmichen M (1978): "Mononuclear Phagocytes in the Central Nervous System." New York: Springer-Verlag.

Oehmichen M (1983): Inflammatory cells in the central nervous system. Prog Neuropathol 5:277-325.

Papa V, Reese CC, Brunetti A, Siiteri PK, Goldfine ID (1990): Progestins increase insulin receptor content and insulin stimulation of growth in human breast carcinoma cells. Cancer Res 50(24): $7858-7862$.

Perry VH, Hume DA and Gordon S (1985): Immunohistochemical 


\section{Ganter et al.}

localization of macrophages and microglia in the adult and developing mouse brain. Neuroscience 15:313-326.

Polan ML, Loukides J, Nelson P, Carding S, Diamond M, Walsh A (1989): Progesterone and estradiol modulate interleukin- 1 beta messenger ribonucleic acid levels in cultures human peripheral monocytes. J Clin Endocrinol Metab 69(6):1200-1206.

Pryjma J, Flad HD, Mytar B, Ennen J, Ernst M (1989): Effect of dexamethasone on mechanisms responsible for regulation of polyclonal B-cell response. Int $\mathbf{J}$ Immunopharmacol I 1(8):87 I877.

Rieske E, Graeber MB, Tetzlaff W, Czlonkowska A, Streit WJ, Kreutzberg GW (1989): Microglia and microglia-derived brain macrophages in culture: generation from axotomizied rat facial nuclei, identification and characterization in vitro. Brain Res 492:1-14.

Rio-Hortega, P del (1932) Microglia. In Penfield W (ed): "Cytology and Cellular Pathology of the Nervous System." New York: Hocker, pp 481-584.

Schnitzer J (1989): Enzyme-Histochemical Demonstration of Micro- glial Cells in the Adult and Postnatal Rabbit Retina. J Comp Neurol 282:249-263.

Seitz M, Dewald B, Gerber N, Bagglioni M (1991): Enhanced production of neutrophil-activating peptide-1 (Interleukin 8 ) in rheumatoid arthritis. J Clin Invest 87:463-469.

Shena M, Yamamoto KR (1988): Mammalian glucocorticoid receptor derivatives enhance transcription in yeast. Science 241:965967.

Streit WJ, Graeber MB, Kreutzberg GW (1988): Functional plasticity of microglia: A review. Glia 1:301-307.

Streit WJ (1990): An improved staining method for rat microglial cells using the lectin from Griffonia simplicifolia $\left(\right.$ GSA I- $\left.\mathrm{B}_{4}\right)$. J Histochem Cytochem 38(11):1683-1686.

Tobler A, Marti HP, Gimmi C, Cachelin AB, Saurer S, Fey MF (1991): Dexamethasone and 1,25-dihydroxyvitamin $D_{3}$, but not cyclosporine $\mathrm{A}$, inhibit production of granulocyte-macrophage colony-stimulating factor in human fibroblasts. Blood 77(9): 1912-1918. 